\title{
Social Work
} \& Education

(C) SW\&E, 2020

УДК 37.013.42:173.7:364-7

DOI: $10.25128 / 2520-6230.20 .3 .2$.

\section{Вадим Лютий, кандидат педагогічних наук, доцент, кафедра соціальної педагогіки та соціальної роботи, Інститут людини Київського університету імені Бориса Грінченка, м. Київ, Україна, v.liutyi@kubg.edu.ua}

ORCIDiD: 0000-0002-9105-0470

\section{Ольга Павлик,} менеджер тренінгових програм МБО "Партнерство "Кожній дитині", студентка магістерської програми, Інститут людини Київського університету імені Бориса Грінченка, м. Київ, Україна, ovpavlyk.i119@kubg.edu.ua

ORCIDiD: 0000-0003-1888-6391

\section{Article history:}

Received: July 26, 2020

1st Revision: August 16, 2020

Accepted: September 30, 2020
Лютий, В., Павлик, О. (2020). Критерії оцінювання якості послуги патронату над дитиною. Vol. 7, No. 3. Ternopil-Aberdeen, 2020. pp. 263-278. DOI: 10.25128/2520-6230.20.3.2.

\section{КРИТЕРІЇ ОЦІНЮВАННЯ ЯКОСТІ ПОСЛУГИ ПАТРОНАТУ НАД ДИТИНОЮ}

Анотація. Патронат над дитиною оцінюється фахівцями як одна із найефективніших моделей реабілітації та соціалізації дитини, яка опинилася у складних життєвих обставинах чи залишилась без батьківського піклування й зазнала травматичних чи соціально-непередбачуваних подій у своєму житті. Наразі створені нормативні та методичні умови для широкого впровадження патронату як соціальної послуги в Україні, проте критерії оцінювання якості даної послуги не визначені, а ефективність реальної практики іiі застосування потребує емпіричного підтвердження.

Автори дослідження на основі аналізу цілей та змісту послуги патронату над дитиною розкривають критерії та індикатори оцінювання якості даної послуги. Методи дослідження: традиційний аналіз нормативних i методичних документів, системний i структурнофункціональний.

Проведений аналіз дозволив виокремити основні цілі застосування патронату над дитиною як соціальної послуги та обгрунтувати критерії оцінювання іiї якості, а саме: забезпечення дитини доглядом відповідно до іiі потреб; нормалізація стану дитини та поліпшення показників ¥ї фізичного й психологічного розвитку, навчання та набуття соціальних навичок; отримання дитиною необхідних медичних та реабілітаційних послуг; врахування прав та інтересів дитини при прийнятті рішень щодо подальшої ऑiі долі; подолання або мінімізація біологічною сім'єю дитини наслідків складних життєвих обставин та створення нею необхідних умов для розвитку та виховання дитини; прийняття своєчасного i обгрунтованого рішення в найкращих інтересах дитини щодо повернення іiі у біологічну сім'ю або влаштування в інші форми сімейного виховання. Для кожного критерія були визначені індикатори, на основі яких він може оцінюватись, та методи, застосування яких в умовах територіальної громади дозволить визначити переваги i можливості запровадження послуги патронату над дитиною, виявити недоліки i ризики та шляхи ïx подолання.

Ключові слова: патронат над дитиною; соціальна послуга; патронатні вихователі; дитина, яка опинилася у складних життєвих обставинах; соціальна реабілітація; соціалізація, оцінювання. 


\section{Вступ}

Однією із найбільш інноваційних соціальних послуг, впровадження яких наразі відбувається в Україні, є послуга патронату над дитиною. На відміну від інших сімейних форм влаштування дитини, яка залишилась без піклування дорослих або за певних обставин не отримує належного догляду та піклування батьків, патронат виступає не альтернативою, а засобом збереження та відновлення іiі біологічної родини. Тимчасове перебування дитини в родині патронатного вихователя, поєднане із соціальним супроводом іiі батьків та наданням інших соціальних послуг, дає можливість дитині відновити сан фізичного та психічного благополуччя та отримати досвід позитивних сімейних відносин, а їі батькам за умов належної мотивації - поступово подолати складні життєві обставини, вирішити найскрутніші проблеми та набути необхідних ресурсів для розвитку та виховання дитини. Експериментальне впровадження послуги сімейного патронату в Україні розпочалося в 2009 р. в рамках проектів МБО «Партнерство «Кожній дитині». Станом на 01.02.2020 в нашій країні функціонувала 101 патронатна сім'я у 20 регіонах, в яких пройшли реабілітацію більше 500 дітей, які опинилися у СЖО або потребували захисту (Розвиток патронатних сімей, 2020). I хоча дієвість патронатного виховання теоретично обгрунтована та експериментально підтверджена в ряді країн, оцінювання реальної практики його застосування в Украӥні, визначення критерїв якості, чинників та умов ефективності послуги патронату над дитиною наразі $\epsilon$ актуальним. Особливо це важливо в контексті реформи системи соціальних послуг та територіальної реформи, що в даний момент відбувається в Україні. Оскільки саме об'єднана територіальна громада (ОТГ) має виступити замовником соціальних послуг, в тому числі - послуги патронату над дитиною, необхідно забезпечити уповноважених осіб ОТГ коректною об'єктивною інформацією щодо можливостей і результатів надання послуги патронату над дитиною в умовах реальної практики та надати їм надійний інструмент оцінювання якості надання даної послуги різними організаціями.

\section{Аналіз останніх досліджень і публікацій}

В наукових працях українських дослідників розглядалися соціальнопедагогічний та правовий аспекти впровадження патронату над дитиною (сімейного патронату, патронатного виховання). Публікації юридичної тематики розкривають правовий статус сімейного патронату, нормативні умови його застосування та характер правовідносин суб'єктів патронату, що при цьому виникає. Автори публікацій даного напряму (Черновалюк, 2009; Римаренко, 2017; Резник, 2019) вказують на подвійну природу соціального патронату (сімейна форма влаштування дитини та соціальна послуга з ії виховання та реабілітації), що відбивається на завданнях, які виконують патронатні вихователі: 3 одного 
боку вони мають тимчасово виступити у ролі опікунів дитини, забезпечивши їй необхідні умови для розвитку, представляючи та захищаючи іï інтереси, з іншого - надати дитині послуги з догляду, виховання та реабілітації, консультувати та підтримувати іï батьків (законних представників).

В соціально-педагогічній літературі та публікаціях із соціальної роботи приділено увагу закономірностям, покладеним в основу патронатного виховання, чинникам та умовам ефективності патронату над дитиною, змісту та методам діяльності патронатних вихователів, соціального супроводу біологічних сімей дітей, які перебувають під патронатом, підбору та підготовці патронатних вихователів. На думку Ж.Петрочко, патронат для дитини, яка отримала травматичний досвід у власній сім'і, $\epsilon$ свого роду «терапевтичним батьківством»; тимчасове перебування в сім'ї патронатного вихователя, застосування ним адекватного виховного підходу та надання психологічної підтримки дозволять дитині отримати досвід позитивних міжособистісних стосунків, побачити та перейняти нові моделі поведінки в сім’ї i, як наслідок, частково відновити особистий потенціал і компенсувати порушення розвитку, викликані втратою прив'язаності та депривацією потреб. Ключовими завданнями патронатного вихователя $є$ формування у дитини відчуття безпеки, створення умов для переживання позитивних емоцій, розвиток базової довіри дитини до інших людей, надання ій допомоги в регуляції власних емоцій, бажань і поведінки, розвиток іiі самоусвідомлення та формування здорової ідентичності (Петрочко, 2014). На думку М.Сидорчук, цілями патронатного виховання, є створення безпечного середовища для дитини, попередження ii інституціалізації, задоволення базових потреб дитини в сімейних умовах, виховання та розвиток дитини та забезпечення іiі прав, а ефективність послуги патронату пов'язана із ii поєднанням із соціальним супроводом біологічної родини дитини, комплексності, узгодженості та професійності дій патронатних вихователів та інших фахівців, що складають міждисциплінарну команду (Сидорчук, 2016). Г.Слозанська вважає, що послуга патронату може бути особливо дієвою при іiї застосуванні на рівні об'єднаної територіальної громади (ОТГ) у випадку необхідності екстреного втручання та влаштування дитини, що зазнала домашнього насильства, в безпечні для неї умови, потрапляння дитини у складні життєві обставини через хворобу та госпіталізацію батьків, раптової втрати біологічної сім’ї, тимчасового влаштування дитини на період вирішення питання щодо іiі постійної опіки (Слозанська, 2018). Таким чином, автори публікацій соціально-педагогічного напряму наголошують на ефективності соціального патронату як засобу відновлення психологічного стану та створення тимчасових умов для соціалізації дитини, яка опинилася без піклування дорослих або зазнала травматичних подій у своєму житті, а також як послуги, що сприяє відновленню функціонування батьківської сім'ї дитини. Проте практична ефективність застосування даного 
підходу як соціальної послуги в реальних умовах територіальних громад України потребує підтвердження. Хоча в науковій літературі не розкритими залишаються критерії та індикатори, на основі яких можна оцінити якість та ефективність послуги патронату над дитиною, визначення науковцями сутності, мети, функцій та змісту даної послуги надає можливість для виконання цього завдання.

\section{Мета та завдання статті}

Метою даної публікації є теоретичне обгрунтування та методологічна розробка системи критеріїв та індикаторів оцінювання якості послуги патронату над дитиною та системи методів, що можуть бути застосовані при оцінюванні якості надання даної послуги в умовах об'єднаної територіальної громади. В ході підготовки публікації вирішувались такі завдання: на основі аналізу нормативних положень та методичних рекомендацій щодо впровадження патронату над дитиною визначити цілі та очікувані результати надання даної послуги; спираючись на сучасну методологію оцінювання соціальних послуг виокремити критерії та індикатори якості застосування патронату та обгрунтувати методи оцінювання якості даної послуги.

\section{Методологія дослідження}

Дослідження на даному етапі носило теоретичний характер і проведене за допомогою наступних методів: традиційний аналіз нормативних та методичних документів, системний та структурно-функціональний аналіз. В якості джерел аналізу було використано науково-методичні публікації 3 питань соціального патронату над дитиною та нормативні документи, що регламентують впровадження даної послуги. На основі аналізу джерел було виокремлено комплекс цілей надання послуги патронату та завдань, що мають бути виконані надавачем. За допомогою структурно-функціонального аналізу та систематизації було визначено перелік критеріїв та індикаторів оцінювання якості послуги патронату над дитиною та методи, що можуть бути використанні при проведенні такого оцінювання.

\section{Основна частина}

Критерії та індикатори оцінювання якості послуги патронату над дитиною $€$ похідними від тих цілей, для досягнення яких ця послуга надається. Відповідно до ст. 252 Сімейного кодексу України, патронат над дитиною - тимчасовий догляд, виховання та реабілітація дитини в сім'ї патронатного вихователя на період подолання дитиною, іiї батьками або іншими законними представниками складних життєвих обставин. За уточненням Ж.Петрочко, послуга патронату може надаватись також на період прийняття рішення про набуття дитиною статусу сироти, дитини, позбавленої батьківського піклування, та визначення 
форми іiі подальшого влаштування (Петрочко, 2014). Метою патронату над дитиною, відповідно до Порядку створення та діяльності сім'ї патронатного вихователя, влаштування, перебування дитини в сім'ї патронатного вихователя, затвердженого Постановою кабінету Міністрів України від 16 березня 2017 р. № 148, є забезпечення захисту прав дитини, яка через складні життєві обставини тимчасово не може проживати разом з батьками/законними представниками, надання ій та іï сім'ї послуг, спрямованих на повернення дитини у сім'ю для забезпечення іiі найкращих інтересів. Автори посібника «Соціальна робота в громаді: ведення випадку та оцінка потреб» до мети патронату також відносять створення умов для подолання батьками обставин, що спонукали до їх розлучення з дитиною, в той період, коли тимчасовий догляд за дитиною, належні умови для ії виховання та розвитку забезпечує патронатний вихователь у своїй сім’ї (Соціальна робота в громаді, 2019).

Як соціальна послуга патронат над дитиною може бути віднесений до комплексної спеціалізованої соціальної послуги, що надаються певній категорії отримувачів соціальних послуг. Виходячи із розглянутих вище нормативних $\mathrm{i}$ методичних документів та наукових публікацій, послуга надається на підставі оцінки потреб дитини та іï сім'ї, оцінки рівня безпеки дитини та, за можливістю, рекомендацій фахівців щодо іiі виховання, догляду, лікування та реабілітації, взаємодії із біологічними батьками за індивідуальним планом соціального захисту дитини. В процесі надання послуги, який може тривати до трьох, а в окремих випадках - до шести місяців, патронатний вихователь за допомогою інших членів своєї сім'ї виконує щодо дитини опікунські функції (забезпечують iï доглядом, необхідними умовами життєдіяльності, навчання та розвитку, представляють та захищають інтереси дитини), вибудовує 3 дитиною підтримувальні взаємовідносини та залучає ii до сімейного спілкування та соціальної взаємодії, надає психологічну підтримку, безпосередньо надає або забезпечує отримання дитиною педагогічних, психологічних, медичних та соціальних послуг відповідно до ії потреб, організовує, за можливості, взаємодію дитини із біологічними батьками або родичами та допомагає їм у подоланні складних життєвих обставин. Одночасно соціальним закладом, на який покладені функції з пошуку, відбору та організації надання даної послуги, здійснюється соціальний супровід біологічної сім’ї дитини, а іiї батьки або законні представники отримають інші соціальні послуги, необхідні для подолання складних життєвих обставин, котрі призвели до необхідності застосування патронату. Контроль умов утримання та виховання дитини в сім’ї патронатного вихователя здійснює служба у справах дітей. Для забезпечення успішності патронату над дитиною та підтримки їі сім'ї створюється міждисциплінарна команда фахівців у складі працівників соціального закладу, патронатного вихователя, служби у справах дітей, освіти, охорони здоров'я та інших закладів та 
установ, дотичних до захисту, реабілітації та розвитку дитини. В результаті надання послуги патронату дитина має повернутися до біологічної сім’ї, якщо останній вдається подолати складні життєві обставини або мінімізувати їхні наслідки, або має бути прийняте рішення щодо альтернативної постійної форми влаштування дитини.

Таким чином, цілями послуги патронату над дитиною, досягнення яких може свідчити про успішність послуги, і які мають бути предметом оцінки їі якості, є:

1) Забезпечення умов для задоволення базових потреб дитини (догляд);

2) Цілеспрямоване формування компетентностей дитини, необхідних для життя в суспільстві (виховання);

3) Створення умов для іiі навчання, фізичного, психічного та духовного розвитку та соціалізації;

4) Захист прав та інтересів дитини;

5) Компенсація або мінімізація наслідків складних життєвих обставин для дитини, нормалізація порушеного внаслідок пережитого травматичного досвіду фізичного i психічного стану дитини, відновлення втрачених навичок (реабілітація);

6) Подолання або мінімізація наслідків складних життєвих обставин сім'єю дитини

7) Створення умов для повернення дитини у біологічну родину або визначення альтернативних форм їі влаштування з урахуванням найкращих інтересів дитини

8) Сприяння створенню належних умов соціалізації дитини у ії біологічній родині або в альтернативних формах їі влаштування.

Оскільки досягнення більшості із названих цілей виходить за часові межі патронату, для оцінки якості даної послуги важливим є визначення ступеню виконання патронатними вихователями та міждисциплінарною командою своїх ключових для досягнення даних цілей завдань:

- створення безпечного середовища для дитини та формування у неї відчуття безпеки;

- побудова 3 дитиною взаємовідносин вторинної прив'язаності, довіри, емоційної підтримки;

- створення умов для переживання позитивних емоцій;

- розвиток базової довіри дитини до інших людей;

- розвиток у дитини навичок соціальної поведінки, самоконтролю, регулювання емоцій;

- розвиток самосвідомості дитини, формування у неї позитивної самооцінки та здорової ідентичності;

- забезпечення доступу дитини та іï біологічних батьків або законних представників, до соціальних послуг, необхідних для подолання їхніх складних життєвих обставин; 
- активізація діяльності біологічних батьків дитини та членів іï сім'ї, спрямованої на подолання складних життєвих обставин та створення належних умов для розвитку і виховання дитини.

Отже, в ході оцінювання якості надання послуги патронату над дитиною має

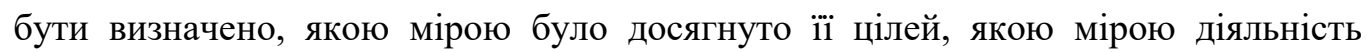
суб'єктів патронату відповідала їх завданням, потребам й інтересам отримувачів даної послуги та вимогам щодо ії надання.

Оскільки мова йде про оцінювання патронату над дитиною як соціальної послуги, його методологія має враховувати положення нормативних документів що регламентують дану діяльність. Згідно із Законом України про соціальні послуги (2019), оцінка якості соціальної послуги - результат показників її якості. Показники ж якості соціальної послуги законом визначаються як сукупність індикаторів, що використовуються для оцінювання процесу та результатів діяльності надавача соціальних послуг на відповідність встановленим вимогам та результативності соціальних послуг щодо профілактики складних життєвих обставин, подолання або мінімізації ї негативних наслідків для осіб/сімей, які перебувають у таких обставинах. Показники якості конкретної соціальної послуги визначаються в стандарті їі надання. Порядок проведення моніторингу надання та оцінки якості соціальних послуг, затверджений постановою Кабінету Міністрів України від 1 червня 2020 р. № 449, визначає оцінку якості соціальних послуг як комплекс заходів, спрямованих на встановлення рівня відповідності наданих соціальних послуг затвердженим державним стандартам соціальних послуг. Порядок передбачає застосування таких методів оцінки якості як опитування отримувачів соціальних послуг або їх законних представників, спостереження за процесом надання соціальних послуг, бесіди (співбесіди) з персоналом надавача соціальних послуг, вивчення документації надавача соціальних послуг, іншої документації, у тому числі звернень отримувачів соціальних послуг. Показників якості надання соціальних послуг порядок не розкриває, проте вони визначені у Методичних рекомендаціях 3 проведення моніторингу та оцінки якості соціальних послуг, затверджених Наказом Міністерства соціальної політики України від 27.12.2013 № 904. Такими показниками, згідно Методичних рекомендацій, $\epsilon$ адресність та індивідуальний підхід; результативність; своєчасність; доступність та відкритість; зручність; повага до отримувача соціальної послуги; професійність. Показники якості соціальних послуг, критерії та індикатори дотримання цих показників наведено у відповідних державних стандартах соціальних послуг.

Як можна побачити, всі перелічені показники, окрім результативності, характеризують процес надання соціальної послуги, є універсальними і мало різняться залежно від виду послуги, що оцінюється. В той же час саме оцінка результатів надання послуги відповідно до ії цілей грає ключову роль у 
визначенні її якості. Стандарту соціальної послуги патронату над дитиною наразі не затверджено отже при оцінці якості даної послуги варто спиратись на результати узагальнення нормативних положень та методики іiі надання.

Відповідно до проведеного аналізу, якість послуги патронату над дитиною можна оцінити на основі таких критеріїв:

1. В ході надання послуги дитина була забезпечена доглядом відповідно до ї вікових та індивідуальних потреб, перебувала у безпечному середовищі. Індикаторами даного критерію можуть бути стан забезпеченості дитини побутовими умовами, одягом, харчуванням протягом надання послуги, їх відповідність санітарно-гігієнічним нормам та потребам дитини; способи визначення патронатним вихователем потреб дитини та реагування на них протягом надання послуги; відповідність вимог патронатного вихователя щодо поведінки дитини іiі потребам та нормам безпеки; динаміка фізіологічних характеристик дитини, стану ii здоров'я, емоційного стану; їх відповідність віковим нормам.

2. Надання послуги сприяло фізичному та психічному розвитку дитини, формуванню ї̈ особистості, поліпшенню ї̈ сочзільних навичок, отриманню належної освіти. Основні індикатори: відповідність заходів, що вживались патронатним вихователем для забезпечення розвитку дитини i набуття нею соціальних навичок, потребам та індивідуальним особливостям дитини, сучасним підходам у вихованні, рекомендаціям відповідних фахівців; систематичність відвідування дитиною навчального закладу, отримання дитиною інших освітніх послуг, динаміка успішності навчання дитини в 33СО; динаміка цінностей та інтересів дитини, розвиток спрямованості ऑii особистості протягом надання послуги; зміни у поведінці дитини в ключових ситуаціях соціальної взаємодії (висловлювання потреб та інтересів, співпраця, конкуренція, конфлікт, подолання фруструючих ситуацій);

3. Права та інтереси дитини були представлені та захищені під час надання nослуги. Індикатори даного критерію: участь патронатного вихователя та представників соціальної установи у заходах, в ході яких визначався статус дитини або приймалися рішення, необхідні для реалізації пї прав та інтересів; представлення та відстоювання ними інтересів дитини в ході таких заходів; прийняття відповідними органами рішень, необхідних для забезпечення прав та інтересів дитини.

4. Внаслідок надання послуги було поліпшено або нормалізовано фізичний та психічний стан дитини, ї̈ поведінка та взаємовідносини, порушені через СЖО. Індикатори: динаміка в ході надання послуги фізичного та психологічний стану дитини, іï самооцінки, впевненість іï у собі, особливості ідентичності дитини; відповідність поведінки та взаємовідносин дитини віковим та соціальним нормам та іiі індивідуальним потребам; характер взаємовідносин дитини із біологічними 
батьками та членами біологічної родини, добровільність, частота та періодичність зустрічей з ними.

5. Дитина отримала медичні та реабілітаційні послуги відповідно до ї̈ потреб. Індикаторами є отримання дитиною послуг фізичної та психологічної реабілітації відповідно до потреб та рекомендацій фахівців, застосування спеціальний реабілітаційних програм; ступінь компенсованості спеціальних потреб дитини, набуття нею компенсаторних навичок.

6. Дитина адаптувалася до життя в сім'ї патронатного вихователя та набула досвіду позитивного сімейного спілкування. Індикатори оцінювання: частота та форми спілкування та характер стосунків дитини з патронатним вихователем та іншими членами сім'ї; психологічний клімат в сім'ї патронатного вихователя протягом періоду надання послуги; ставлення дитини до патронатного вихователя, його помічника та інших членів його сім'ї, ступінь довіри до них, дотримання нею норм та правил сім'ї патронатного вихователя.

7. Соиіальний супровід та надання інших соиіальних послуг сприяло подоланню біологічною сім'єю дитини складних життєвих обставин та створенню необхідних умов для розвитку та виховання дитини. Індикатори: частота та періодичність та тематика зустрічей представників біологічної сім'ї дитини 3 працівником, який веде даний випадок, та іншими членами міждисциплінарної команди; надання членам сім'ї соціальних послуг відповідно до їхніх потреб сім'ї та плану роботи із сім'єю; активність членів біологічної сім'ї дитини, спрямована на подолання проблем та СЖО або на мінімізацію їх наслідків, створення належних умов виховання та розвитку дитини; зміни в поведінці та взаємовідносинах членів сім'ї.

8. Рімення щодо повернення дитини в біологічну сім'ю або ї̈ влаштування в інші сімейні форми відповідало найкращим інтересам дитини. Індикаторами $\epsilon$ врахування обставин та умов, створених для розвитку та виховання дитини, індивідуальних особливостей дитини та іï потреб та інтересів, власної думки дитини при прийнятті рішення щодо повернення дитини у біологічну сім'ю або виборі альтернативної форми її влаштування.

9. Дитина та ї̈ біологічні батьки або законні представники дитини в альтернативних формах ї̈ вламтування отримали підтримку в ході адаптаиї після завершення патронату. Індикатори: кількість, частота та форми організації зустрічей патронатного вихователя та інших членів міждисциплінарної команди 3 біологічними батьками або законними представниками дитини в інших формах ii влаштування, їхня тематична спрямованість; відповідність інформації, порад та рекомендацій, наданих патронатними вихователями та іншими членами міждисциплінарної команди біологічним батькам або законним представникам дитини в інших формах іiі влаштування індивідуальним особливостям, потребам та інтересам дитини та сучасним підходам до розвитку і виховання дітей 
10. Надання послуги патронату сприяло поліпшенню умов розвитку та соиіалізаџії дитини, ступеню ї̈ соціалізованості та інтегрованості у тривалій часовій перспективі. Індикатори: відповідність розвитку, поведінки та взаємовідносин дитини віковим та соціальним нормам протягом року по завершенні надання послуги; відповідність умов життєдіяльності та розвитку дитини її потребам та індивідуальним особливостям протягом року по завершенні патронату; характер проблем, що виникали у дитини та у іï біологічних батьків або представників протягом року по завершенні надання послуги; суб'єктивна оцінка послуги та її впливу на розвиток дитини самою дитиною та їі біологічними батьками або законним представниками.

Окрім перелічених вище критеріїв якості послуги патронату над дитиною, що характеризують процес та результати досягнення цілей даної послуги, для оцінки якості важливими можуть бути також критерії відповідності умов надання даної послуги таким, що не обхідні для отримання бажаних результатів. Серед таких критеріїв варто виділити:

1. Критерії адресності та індивідуального підходу: надання послуги на основі оцінки проблем і потреб дитини та сім’ї, наявність індивідуального плану надання послуги, що відповідав би виявленим потребам та індивідуальним особливостям дитини й особливостям іiі сім’ї; проведення проміжної оцінки надання послуги та корекції плану;

2. Критерії своєчасності надання послуги: швидкість реагування на звернення дитини або іiі батьків або на отримання інформації про сім'ю 3 дитиною, що перебуває в СЖО; прийняття рішення щодо надання послуги в термін, що відповідає стану дитини та ступеню загрози, що несуть СЖО; дотримання передбачених планом термінів;

3. Критерії доступності та відкритості: надання послуги та здійснення заходів у зручних та доступних для отримувачів формах; надання вичерпної інформації про послугу та умови їі надання, очікувані результати дитині (якщо вона здатна усвідомлювати відповідну інформацію) та їі батькам в доступних для них формах;

4. Критерії поваги до гідності отримувачів послуги: надання послуги за згодою дитини та їі біологічних батьків або законних представників, якщо інше не передбачене нормативними документами; дотримання патронатними вихователями та членами міждисциплінарної команди норм професійної та загальнолюдської етики; відсутність дій та рішень надавачів послуги, що порушують права та дискримінують будь-кого із отримувачів послуги;

5. Критерії професіоналізму надавачів послуги: відбір патронатних вихователів за рекомендованими критеріями; отримання патронатними вихователями та членам міждисциплінарної команди відповідної підготовки; надання супервізійної підтримки патронатним вихователям; систематична 
взаємодія учасників міждисциплінарної команди відповідно до плану надання послуги; проведення систематичного підвищення кваліфікації членів міждисциплінарної команди.

Результати оцінювання за останніми критеріями можуть бути корисними для не лише для визначення якості надання послуги патронату, а й для пошуку відповідей на запитання щодо причин низької якості або проблем, що виникають при наданні послуги.

Оцінювання якості послуги патронату над дитиною за вказаними критеріями можливо як на рівні окремого випадку, так і на рівні діяльності надавача даної послуги. При оцінці на рівні випадку доцільно застосовувати такі методи як опитування патронатного вихователя, дитини, іiі біологічних батьків у формі анкетування та формалізованого, фокусованого або глибинного інтерв'ю, спостереження за поведінкою дитини та взаємовідносинами в сім'ї патронатного вихователя та біологічної сім'ї дитини, традиційний аналіз документів, що висвітлюють процес та результати надання послуги патронату (особова справа дитини та сім'ї, акт оцінки потреб дитини та іï сім'ї, план соціального захисту дитини та соціального супроводу сім'ї, журнал спостережень тощо), експертне оцінювання, методи психодіагностики. При оцінці послуги на рівні організаціїнадавача або громади можливе узагальнення оцінки всіх випадків надання послуги або формування вибірки випадків, доповнене фокус-групами патронатних вихователів, біологічних батьків, працівників соціальних установ, членів міждисциплінарних команд, а також інтерв'ю із представниками замовника послуги, лідерами громад тощо.

\section{Висновки та перспективи подальших досліджень}

Сімейний патронат над дитиною $\epsilon$ одночасно як сімейною формою тимчасового влаштування дитини, яка залишилася без піклування батьків або за певних обставин не може отримати у власній біологічній родині належного догляду і виховання, так і соціальною послугою, спрямованою на запобігання інституціалізації дитини, збереження іiі біологічної родини та подолання ними складних життєвих обставин. Данна послуга передбачає поєднання догляду i виховання дитини в сім'ї патронатного вихователя, надання дитині реабілітаційних послуг та здійснення соціального супроводу іiї біологічної сім'ї. Цілями даної послуги можуть бути забезпечення умов для задоволення базових потреб дитини, навчання, фізичного, психічного та духовного розвитку та соціалізації, захист прав та інтересів дитини, подолання нею наслідків пережитих складних життєвих обставин та відновлення порушених внаслідок пережитого травматичного досвіду фізичного і психічного стану дитини, подолання або мінімізація наслідків складних життєвих обставин сім'єю дитини та створення умов для повернення до неї дитини або для вибору іншої форми влаштування 
дитини із найкращим урахуванням іiі інтересів. Встановлення рівня досягнення названих цілей має бути основним показником оцінки якості послуги патронату над дитиною. Аналіз положень нормативних і методичних документів щодо патронату над дитиною у якості критеріїв оцінювання його якості дозволив визначити: забезпечення дитини доглядом відповідно до ії потреб, перебування дитини у безпечному середовищі; поліпшення або нормалізація показників фізичного і психологічного розвитку дитини, навчання та набуття нею соціальних навичок; врахування прав та інтересів дитини при прийнятті рішень щодо іiі подальшої долі; нормалізацію фізичний та психічний стан дитини, ії поведінки та взаємовідносин; отримання дитиною необхідних медичних та реабілітаційних послуг; адаптованість дитини в умовах сім’ї патронатного вихователя; подолання або мінімізація біологічною сім'єю дитини наслідків складних життєвих обставин та створення нею необхідних умов для розвитку та виховання дитини, прийняття своєчасного і обгрунтованого рішення в найкращих інтересах дитини щодо повернення іï у біологічну сім'ю або влаштування в інші форми сімейного виховання та адаптація дитини до них. Оцінка якості надання послуги патронату над дитиною на основі даних критеріїв в реальних умовах територіальних громад дозволить визначити переваги і можливості іiі застосування, виявити недоліки і ризики та шляхи їх подолання.

Перспективи подальшого дослідження проблеми: апробація критеріїв та індикаторів оцінки якості послуги патронату над дитиною та методики оцінювання в умовах експериментальної об'єднаної територіальної громади та проведення на основі апробованої та удосконаленої методики оцінки якості даної послуги.

\section{Література}

Закон України Про соціальні послуги (2019). Відновлено 3 https://zakon.rada.gov.ua/laws/show/2671-19\#Text.

Деякі питання здійснення патронату над дитиною. Постанова кабінету $\begin{array}{lllllll}\text { Міністрів України від № } 148 & \text { (2017). Відновлено } 3\end{array}$ https://zakon.rada.gov.ua/laws/show/148-2017-п\#.

Петрочко, Ж. В. (2014) Теоретичні основи патронату над дітьми. Соціальна педагогіка: теорія та практика. 2014. № 1. - С. 83-90.

Про затвердження Порядку проведення моніторингу надання та оцінки якості соціальних послуг. Постанова кабінету міністрів України № 449 (2020). Відновлено з https://zakon.rada.gov.ua/laws/show/449-2020-п/print.

Про затвердження Методичних рекомендацій з проведення моніторингу та оцінки якості соціальних послуг. Наказ Міністерства соціальної політики України № 904 (2013). Відновлено з https://zakon.rada.gov.ua/rada/show/v0904739-13/print. 
Розвиток патронатних сімей є одним із пріоритетів Мінсоцполітики на 2020 рік. (2020). Урядовий портал. Відновлено з https://www.kmu.gov.ua/news/rozvitokpatronatnih-simej-ye-odnim-iz-prioritetiv-minsocpolitiki-na-2020-rik-oleg-koval.

Римаренко, I. (2017) Сімейний патронат як інновація у сімейному праві України. Вісник Академії прачі, соиіальних відносин і туризму. 2017. № 2. - С. 3946.

Резнік, Г. О (2019). Особливості інституту патронатного виховання. Приватне право і підприємництво. 2019. Вип. 19. - С. 106-109.

Сімейний кодекс України.

Відновлено 3 https://zakon.rada.gov.ua/laws/show/2947-14\#.

Сидорчук, М. С. (2016). Послуга сімейного патронату як альтернатива центрам соціально-психологічної реабілітації та притулкам. Наукові записки Ніжсиського державного університету ім. Миколи Гоголя. Психолого-педагогічні науки. 2016. № 1. C. 81-84.

Слозанська, Г. І. (2018) Послуга патронату в системі захисту та підтримки сімей 3 дітьми в об'єднаній територіальній громаді Науковий часопис Начіонального педагогічного університету імені М. П. Драгоманова. Серія 11 : Соціальна робота. Соціальна педагогіка. 2018. Вип. 24(1). С. 214-222.

Соціальна робота в громаді: ведення випадку та оцінка потреб. Тренінг для спеціалістів/фахівців із соціальної роботи. Матеріали для учасника. (2019) К.: Партнерство «Кожній дитині». Відновлено 3 https://issuu.com/p4ecua/docs/training_4_materialsparticipants.

Черновалюк, Ю. Ю. (2009) Патронат як форма сімейного влаштування дітейсиріт та дітей, позбавлених батьківського піклування за законодавством України. Університетські наукові записки. 2009. №1 (29). С. 134-138. 


\section{CRITERIA FOR QUALITY ASSESSMENT OF THE SERVICE "PATRONAGE OVER A CHILD"}

Vadym Liutyi, Candidate of Pedagogical Sciences, Associate Professor, Human Institute of Kyiv University Boris Grinchenko, Kyiv, Ukraine; v.liutyi@kubg.edu.ua

Olga Pavlyk, Traning Programmes Manager, MA student Institute of Kyiv University Boris Grinchenko, Kyiv, Ukraine; ovpavlyk.il19@kubg.edu.ua

Abstract. Short-term emergency fostering ("patronage over a child") is assessed by the specialists as one of the most effective models for rehabilitation and socialization of a child in difficult life circumstances or deprived of parental care, a child that has experienced traumatic or socially unpredictable events while in family environment. Normative and methodological preconditions for wide introduction of patronage as a social service in Ukraine are already in place. However, criteria for quality assessment of the mentioned service are not defined and effectiveness of the service needs empirical evidence.

Therefore, authors of the present research discuss the criteria and indicators for carrying out assessment of the service. Methods of their research include traditional analysis of normative and methodological documents, systemic, structural and functional analysis.

The analysis carried out leads the authors to define the main objectives for introduction of patronage as a social service, namely:

- providing conditions for satisfaction of the basic needs of a child, their education as well as physical, psychological and mental development, socialization;

- protection of the rights and interests of the child;

- overcoming effects of difficult life circumstances experienced by a child and restoration of the physical and psychological state that was distupted by traumatic experience;

- overcoming or minimization of the effects of difficult life circumstances experienced by the child's family and development of preconditions for return of the child or selection of an alternative placement based on best interests of the child.

Building on the goals of patronage, a set of quality assessment criteria is found well-justified, namely:

- providing care for a child, base on its needs, providing safe environment;

- improvement of child's physical and psychological development indicators, education and development of social skills;

- incorporation of the rights and interests of the child into the process of making decisions regarding its further destiny; 
- normalization of physical and psychological state of the child, its behavior and interactions;

- provision of necessary medical and rehabilitations services;

- overcoming or minimization of the effects of difficult life circumstances by the biological family and establishment of necessary conditions for development and education of a child by this family;

- timely and well-argued decision regarding reuniting the child with the biological family or placement of the child in other forms of family care, which takes best interests of the child into account.

For each of the mentioned criteria authors define a set of indicators, based on which fulfillment of the criteria can be assessed, as well as methods that, when used in the environment of amalgamated communities, will allow for identification of benefits and opportunities for introduction of the patronage over a child services, as well as shortcomings and risks and the ways for minimizing them.

Key words: patronage; short-term emergency fostering; social service; patronage carers; emergency foster carers; child in difficult life circumstances; social rehabilitation; socialization; assessment.

\section{References}

Law of Ukraine "On Social Services" (2019). Retrieved from https://zakon.rada.gov.ua/laws/show/2671-19\#Tex [In Ukrainian].

Selected Issues of Carrying out Patronage over a Child. Decree of the Cabinet of Ministers of Ukraine No.148 (2017). Retrieved from https://zakon.rada.gov.ua/laws/show/148-2017-п\#Text [In Ukrainian].

Petrochko, Z. (2014): Theoretical Basis of the Patronage over a Child. In: Social Pedagogy: Theory and Practice, 2014, No.1., pp. 83-90. [In Ukrainian].

On Approval of the Order of Carrying out Social Services Monitoring and Quality Assessment. Decree of the Cabinet of Ministers of Ukraine No.449. (2020) Retrieved from https://zakon.rada.gov.ua/laws/show/449-2020-n/print [In Ukrainian].

On Approval of the Methodology Recommendations for Carrying out Social Services Monitoring and Quality Assessment. Order of the Ministry of Social Policy of Ukraine No.904. (2013). Retrieved from https://zakon.rada.gov.ua/rada/show/v0904739-13/print [In Ukrainian].

Patronage families development is a priority of Ministry of Social Policy on 2020. (2020). Government portal. Retrieved from https://www.kmu.gov.ua/news/rozvitokpatronatnih-simej-ye-odnim-iz-prioritetiv-minsocpolitiki-na-2020-rik-oleg-koval [In Ukrainian].

Rymarenko, I. (2017): Family Patronage as an Innovation in Family Law of Ukraine. In: Labour, Social Relations and Tourism Academy's Herald, 2017, No.2., pp. 39-46. [In Ukrainian]. 
Reznik, H. O. (2019): Features of the Patronage Education Public Institute. In: Private Law and Entrepreneurship, 2019, No.19, pp. 106-109. [In Ukrainian].

Family Code of Ukraine. Retrieved from https://zakon.rada.gov.ua/laws/show/294714\#Text [In Ukrainian].

Sydorchuk, M. S. (2016): Family Patronage Servies as an Alternative for Centers of Social and Psychological Rehabilitation and Shelters. In: Proceedings [of the Nizhyn State Mykola Hohol University]. Psychological and Pedagogical Sciences, 2016, No.1, pp.81-84. [In Ukrainian].

Slozanska, G. I. (2018): Patronage Services in the System of Protection and Suppoprt of the Families in Amalgamated Communities. In: Scientific Journal of the National Pedagogical M.P. Drahomanov University, Series 11: Social Work. Social Pedagogy, 2018, Issue 24(1), pp.214-222. [In Ukrainian].

Social Work in Community: Case Management and Needs Assessment. Training for Social Work Specialists / Experts. Participant's Band. (2019) . Kyiv, Partnership for Every Child. Retrieved from: https://issuu.com/p4ecua/docs/ training_4_materialsparticipants [In Ukrainian].

Chernovaliuk, I. I. (2009): Patronage as a Form of Family Placement for Orphans and Children Deprived of Parental Care, According to Legislation of Ukraine. In: University's Proceedings, 2009, No.1(29), pp.134-138. [In Ukrainian]. 